\title{
ANAGNÓRISIS AL DISEÑO INSTITUCIONAL DEL PODER JUDICIAL CHILENO: JUECES IMPARCIALES HASTA QUE COMIENZAN A SERLO
}

\author{
ANAGNORISIS IS ON THE INSTITUTIONAL DESIGN OF THE \\ CHILEAN JUDICIARY: IMPARTIAL JUDGES UNTIL THEY \\ BEGIN TO BE SO
}

PATRICIO RONDINI FERNÁNDEZ-DÁVILA***

\section{RESUMEN}

El diseño institucional del Poder Judicial chileno reúne las condiciones para afectar la imparcialidad judicial. Ello se debe a que establece un sistema de carrera funcionaria altamente discrecional, donde es el interés personal, y no las razones del derecho, lo que mueve al juez. Los incentivos y castigos predeterminan el comportamiento de los jueces en desmedro de la jurisdicción, sin que sea necesaria solicitud u orden expresa porque el propio sistema señala a los jueces cómo deben actuar para tener una carrera exitosa y evitar el castigo. Esto promueve la perdida de imparcialidad del juzgador porque el objeto del proceso no le resulta indiferente al juez, dado que es el medio para ascender dentro de la organización judicial.

Palabras Clave: Poderjudicialchileno; Imparcialidadjudicial; Independencia judicial; Estructura judicial; Carrera funcionaria; Jurisdicción.

\footnotetext{
*Abogado, Magister Universidad Austral, Valdivia, Chile. Correo electrónico: patriciorondini@gmail.com **Este trabajo obedece a las obligaciones de publicaciones que impone el programa de doctorado de la Universidad Austral de Chile y tiene un carácter estrictamente académico.

Trabajo recibido el 19 de agosto de 2019, y aprobado para su publicación el 8 de diciembre de 2019 .
} 


\section{ABSTRACT:}

The institutional design of the Chilean judicial branch meets the conditions to affect judicial impartiality. This is because it establishes a highly discretionary judicial career system, where it is the personal interest, and not the legal reasons, that moves the judge. Incentives and punishments predetermine the behavior of judges at the expense of the jurisdiction, without requiring an express request or order, because the system itself indicates to the judges how they should act to have a successful career and avoid punishment. This promotes the loss of impartiality of the judge because the object of the process is not indifferent for him, since it is the means to ascend within the judicial organization.

Keywords: Chilean judicial branch; Judicial impartiality; Judicial independence; Judicial structure; Judicial career; Jurisdiction.

\section{INTRODUCCIÓN}

Los griegos utilizaron la palabra anagnórisis para referirse al reconocimiento de algo y que, en literatura, da cuenta de un hecho que permanecía oculto para que, tras su revelación, el protagonista cambie su destino para bien o para mal. Estas líneas buscan sacar a la luz que un diseño institucional del poder judicial, en el cual se contemplan beneficios o castigos subjetivos y discrecionales, crea las condiciones para impactar negativamente en la imparcialidad judicial. La revelación es que si bien se predica la necesidad de jueces imparciales cuando estos comienzan a serlo pueden aparecer mecanismos de la estructura judicial que lo impiden. Este reconocimiento debe servir de base para generar un cambio hacia una organización de la jurisdicción como garantía de la función jurisdiccional imparcial.

La problemática de la organización de la jurisdicción usualmente es abordada en términos de independencia judicial interna o externa. La primera se afecta cuando existen presiones al juez para apartarlo del derecho desde el propio poder judicial, mientras que en la segunda esa presión proviene desde fuera de la organización judicial. Si el diseño institucional del poder judicial, con algún grado de discrecionalidad, otorga a alguien injerencia en los beneficios o castigos de los jueces, esa persona está en condiciones 
de hacerle peticiones en desmedro de su sujeción únicamente al derecho. Aquí no hay una dificultad de anagnórisis porque la relación entre estructura judicial e independencia del juez es clara en los términos expuestos $\mathrm{y}$, por lo mismo, el estudio se centra en dónde hay opacidad, esto es, en el lazo concurrente entre dicha estructura y la imparcialidad judicial, dando cuenta de por qué ello es así y de los riesgos que implica.

El trabajo comienza con un análisis teórico que brinda las bases conceptuales para comprender el poder judicial en general. Continúa el estudio volcando, de manera crítica, el contenido jurídico expuesto al Poder Judicial chileno, enfatizando sus inconsistencias y las tensiones que se generan.

\section{ORGANIZACIÓN DE LA JURISDICCIÓN E IMPARCIALIDAD JUDICIAL}

\section{Consideraciones generales.}

Antes que todo, corresponde precisar que el sintagma "poder judicial" es ambiguo pues puede hacer referencia a dos sentidos diversos: uno jurisdiccional que corresponde individualmente a cada juez, y otro orgánico que mira al conjunto de la judicatura, que lo entiende como un órgano de justicia compuesto por todos los jueces entre los que se divide y coordina el trabajo. En dicho sintagma se confunde la función con el órgano que ejerce la función, de modo que resulta de particular importancia manejar los dos sentidos del poder judicial, el jurisdiccional y el organizativo, para identificar en cuál de estos se sitúa el discurso y, especialmente, para tratar las relaciones que entre uno y otro deben darse. ${ }^{1}$ Acá el discurso es desde lo organizativo a lo jurisdiccional, en tanto busca establecer cómo el diseño institucional del poder judicial puede afectar una función jurisdiccional imparcial.

\footnotetext{
${ }^{1}$ Atria plantea que existe un poder judicial en sentido propio, que se escribe con mayúsculas, y otro impropio, que se escribe con minúscula, para identificar cuando, en el primer caso, se refiere al ejercicio de la jurisdicción por parte de un juez de aquel, otro caso, en que se hace mención a la organización judicial. Cfr. AtriA, Fernando, La forma del derecho, Marcial Pons, Buenos Aires, 2016, p. 216.

Cabe advertir, como bien podrá haber observado el lector, que aquí en ocasiones poder judicial se escribe con mayúsculas y en otras con minúscula, ello no es empleado en el sentido de ATRIA, sino que de las reglas de la RAE, en tanto corresponde usar minúsculas cuando es un uso genérico y con mayúscula cuando se refiere a uno particular.
} 
La imparcialidad judicial ha ido de la mano con el desarrollo de la jurisdicción, en tanto la sola idea de heterocomposición supone considerar a un tercero que no estuviera involucrado en el asunto, bajo la premisa que nadie puede ser juez y parte (nemo iudex in causa propria), es decir, se exige impartialidad. ${ }^{2}{ }^{3}$ Sin perjuicio de lo anterior, es necesario ahondar en el análisis porque no basta con ser un tercero entre partes, dado que el juez debe decir el derecho exclusivamente por las razones que el derecho le suministra ${ }^{4} \mathrm{y}$, en consecuencia, la función jurisdiccional exige imparcialidad, más allá de la impartialidad, e independencia judicial. La imparcialidad establece una relación entre el juez y el proceso, mientras que la independencia vincula al juzgador con el exterior del proceso, aunque en ambos casos el resultado es el mismo, el juez se aleja de las razones del derecho, pero por motivos distintos. En el primer caso, el juez presenta un compromiso personal con las partes o el objeto del proceso, mientras que, en el segundo, el juez recibe presiones desde el mismo poder judicial o bien de otro poder estatal para apartarlo del derecho.

Siempre la falta de independencia judicial trae aparejada la ausencia de imparcialidad porque un juez que sucumbe a las presiones adquiere un compromiso que lo vuelve parcial, mientras que no ocurre lo mismo en el caso contrario. Las causas de la parcialidad del juez pueden provenir de motivos diversos a los de una presión, como es el caso del parentesco de este con alguna de las partes o interesados. Así las cosas, invariablemente un problema de independencia judicial es también uno de imparcialidad, pero un conflicto de parcialidad puede no serlo de independencia, dado que esta última es condición necesaria pero no suficiente de la primera. Es importante entonces mantener esta distinción porque si bien hay casos en los cuales ambas propiedades tienden a confundirse, no es menos cierto que

\footnotetext{
2 Ya en el derecho romano, el Código de Justiniano establecía como ley general, que nadie debe ser juez de sí mismo o declarar derecho para sí porque es injusto conceder a cualquiera la facultad para proferir sentencia sobre cosa propia. Cfr. Código de Justiniano, L. III, T. V, 1. Extraído de GARCía DEL Corral, Ildefonso (dir.), Cuerpo del Derecho Civil Romano, Ed. Jaime Molinas, Barcelona, 1892, Tomo I.

3 Perfecto ANDRÉs manifiesta que la imparcialidad "ha generado desde antiguo notable preocupación. Al extremo de que, en algunas experiencias históricas, se llega a considerar que en nadie se daría de manera tan genuina esa condición como en el sujeto reclutado fuera de las propias fronteras (...) En los municipios medievales italianos esta fue una práctica regular". Andrés, Perfecto, El tercero en discordia, Trotta, Madrid, 2015, p. 212.

${ }^{4}$ Cfr. Aguiló, Josep, "Los deberes internos a la práctica de la jurisdicción. Aplicación del derecho, independencia e imparcialidad", Revista Jurídica de les Illes Balears, 2012, núm. 10, p. 10
} 
en otros no es así y, por lo mismo, sigue prestando utilidad diferenciar entre imparcialidad e independencia judicial.

Conforme a lo expuesto, por imparcialidad ha de entenderse la falta de compromiso personal del juzgador, ya sea con relación a las partes o al objeto del proceso, lo que es distinto de la neutralidad, aplicación no valorativa del derecho, porque puede ocurrir que el mismo derecho cumpla una función protectora que el juzgador debe considerar, como es el caso de la protección del trabajador en materia laboral o el interés superior del niño en materia de familia. Le está vetado al juez ejercer jurisdicción si tiene un interés personal al interior del proceso porque ello importaría desviar la decisión a razones ajenas al derecho, de modo que el juez no hubiera resuelto de la misma forma de no haber mediado a su respecto dicho interés.

El único interés del juez es con el derecho, y en la medida que se aleja de este, por un compromiso al interior del proceso, pasa a ser parcial, haciendo colapsar la jurisdicción por la ausencia de una de sus propiedades necesarias. En este sentido, AgulLó manifiesta que "la imparcialidad trata de controlar los móviles del juez frente a influencias extrañas al Derecho provenientes del proceso". ${ }^{5}$ Con base a esto, quien propicia la actividad jurisdiccional exige que quien lo juzga proceda conforme a las razones del derecho y no por las propias: es esto lo definitorio de la imparcialidad. Ello obedece a la confianza que, a través de los siglos, se brinda a la heterocomposición como mecanismo de resolución de conflictos pacíficos, en cuanto se cree que un tercero puede dar una mejor respuesta que las partes al asunto porque precisamente no está involucrado en él, y de paso evitar la eventual violencia que pudiera derivar de una autocomposición.

Si bien el juez debe ser imparcial no ocurre lo mismo con las partes o interesados, los que son parciales. ${ }^{6}$ La parcialidad que en el juez es un defecto, resulta deseable en las partes o interesados porque será su interés particular lo que los motivará a avanzar en la resolución del asunto o en el pronunciamiento que se ha solicitado. Esto lo explica CAlAmandreI, respecto de los asuntos contenciosos, cuando señala que "imparcial debe

\footnotetext{
5 Aguiló, Josep, "De nuevo sobre 'Independencia e imparcialidad de los jueces y argumentación jurídica”. Jueces para la democracia, 2003, n 46, p. 52.

${ }^{6}$ Sobre esta idea Carlos PiCADo expresa: "Así como el abogado litigante es y debe ser, necesariamente, parcial, es decir, defender a su parte, (pues de lo contrario seria una nefasta repetición de Juez donde el principal perjudicado seria su defendido); el Juez debe ser imparcial pues sobre el descansa el entero aparato de Justicia". PICADO, Carlos, "El Derecho a ser juzgado por un juez imparcial", IUDEX, 2014, $\mathrm{N}^{\circ}$ II (agosto), pp. 31-62, p. 39.
} 
ser el juez, que es uno, por encima de los contendientes; pero los abogados están hechos para ser parciales, no solo porque la verdad se alcanza más fácilmente escalándola desde dos partes, sino porque la parcialidad de uno es el impulso que engendra el contraimpulso del adversario". ${ }^{7}$ Lo esperable de las partes es que actúen por su interés: no así en el caso del juez, el que deberá abstenerse de conocer o bien será apartado en caso contrario.

Las precisiones realizadas precedentemente brindan el contenido teórico mínimo que permite adentrarse en el objeto del presente trabajo: la relación entre estructura judicial e imparcialidad. Tarea que comienza a realizarse desde el próximo punto.

\section{Vínculo entre estructura judicial e imparcialidad}

Al hacer referencia a la imparcialidad judicial se mencionaron dos fuentes por las cuales el juez se aleja de las razones del derecho y se vuelve parcial, esto es, su interés personal (1) con las partes o (2) con el objeto del proceso. A efectos del presente análisis resulta pertinente centrarse en los problemas de imparcialidad del juez en torno al objeto del proceso, dado que es ahí, según se verá, donde puede haber una vinculación entre diseño institucional del poder judicial e imparcialidad.

Corresponde explicar cómo se relaciona la imparcialidad con la organización judicial porque es contraintuitivo que, si esta mira al interior del proceso, se vea afectada por una cuestión externa, como es el diseño institucional del poder judicial. Pareciere que si la organización de la jurisdicción contempla mecanismos de presión a los jueces se trataría de un problema exclusivamente de independencia porque estos son extraproceso. La organización judicial crea las condiciones para afectar la imparcialidad del juez siempre que se den dos condiciones, esto es, (1) que contemple, subjetiva y discrecionalmente, beneficios o castigos para el juez, y (2) que nadie ofrezca o amenace con estos al juzgador porque, de lo contrario, se trataría de un problema de independencia. ${ }^{8}$

7 Calamandrei, Piero, Elogio de los jueces escrito por un abogado, traducción por Santiago Sentís e Isaac J. Medina, Góngora, Madrid, 2009, p. 97.

8 En el mismo orden de ideas Diego ÍÑIGUEZ expresa: "Es evidente que hay muchas formas de influir sobre la voluntad de un juzgador que operan más discreta, pero no menos intensamente que la presión o la amenaza directa: por ejemplo, la amenaza de postergación o la perspectiva de ascenso. Una y otra pueden ser eficaces en forma positiva, como sugerencia o expectativa individual, pero también en forma negativa, mediante un sistema que permita percibir el ascenso o la pretensión como una consecuencia 
Lo que aquí se consigna es que cuando la organización judicial coloca delante del juez premios sin parámetros objetivos $\mathrm{y}$, por lo mismo, sujetos a la discrecionalidad de un tercero - tales como ascensos, mejoras de remuneraciones u otros-, o bien la amenaza subjetiva de un castigo -como puede ser una mala calificación, un traslado o una sanción disciplinaria-, crea las condiciones para que nazca en el juez un interés en beneficiarse o en evitar el castigo. Ello lo puede llevar a apartarse de su deber de fallar por las razones que el derecho le suministra y, a la vez, lo incentiva hacerlo por interés personal, con la consecuente perdida de imparcialidad al no serle indiferente el objeto del proceso. Aquí nadie pide nada al juzgador, sino que es el propio diseño institucional del poder judicial el que se encarga de tensionar al juez entre su deber jurisdiccional y el interés personal. ${ }^{9}$

La organización judicial en base a beneficios y castigos discrecionales, con una jerarquía y una estructura de tipo napoleónico o de juez funcionario, siguiendo a Perfecto ANDRÉs, es el antimodelo en que no son necesarias órdenes explícitas ${ }^{10}$ pues, según las palabras de BINDER y OBANDO, existe un mandato implícito de adaptación, ${ }^{11}$ el que a este respecto resulta negativo. Lo cual significa que el diseño institucional somete al juez a una serie de ataduras que le restan posibilidades de una actuación imparcial al momento de resolver, sin que sea necesario pedirle algo porque el propio modelo se encarga de mostrarle lo que debe hacer si quiere una carrera judicial rápida

de sus resoluciones jurisdiccionales". ÍñIGUEZ, Diego, El fracaso del autogobierno judicial, Thomson Civitas, fundación Alfonso Martín Escudero, Madrid, 2008, p. 63.

9 Descendiendo del plano teórico al funcional, una muestra de lo expuesto son las palabras del Ministro de Justicia de Chile, Hernán Larraín, cuando en un encuentro partidario, en abril de 2018, señalaba que el poder judicial estaba integrado por jueces de izquierda y que había que "netearlos". Lo cual significaba la búsqueda de jueces de su misma corriente política para igualarlos con los nombrados por gobiernos anteriores, de una visión política distinta. El problema se genera porque el nombramiento de los jueces los realiza el presidente de la República y, en ese sentido, hay un claro mensaje a los jueces en orden a si quieren ser nombrados o ascender debe tratarse de jueces de derecha. Si se observa no es un problema de independencia porque no se le dice a un juez como resolver un caso específico, sino que es un asunto de imparcialidad, dado que, el juez pasa a tener interés en el objeto del proceso porque este es un instrumento para obtener un ascenso en su carrera funcionaria o, en caso contrario, le significará quedar marginado de cualquier nombramiento. La noticia tuvo amplia repercusión, lo cual puede apreciarse en el análisis que realiza Francisco Cox en su Opinión: "El resto es ingenuidad", publicada en periódico La Tercera P.M., edición digital, 10 de marzo de 2018, documento disponible en línea: https://www.latercera.com/la-tercera-pm/noticia/el-resto-es-ingenuidad/128806/ (fecha de consulta: 23 de marzo de 2019).

${ }^{10}$ Cfr. Andrés, Perfecto, Cultura constitucional de la jurisdicción, Siglo del Hombre Editores, Universidad EAFIT, Bogotá, 2011, p. 114.

${ }^{11}$ Cfr. Binder, Alberto; OBAndo, Jorge, De las "Repúblicas Aéreas" al Estado de Derecho, Editorial AdHoc, Buenos Aires, 2004, p. 161. 
y exitosa, en desmedro de su imparcialidad. ${ }^{12}$

Como bien expresa Montero Aroca, "puede decirse que se empieza a ser independiente o se empieza a dejar de serlo desde el mismo momento del nombramiento, atendido el sistema de selección, y que todo el sistema conformador de la carrera judicial (...) pueden o no estar preordenados para seguir garantizando la independencia o para permitir al poder político vulnerarla". ${ }^{13}$ La misma idea la plasma claramente CALAMANDREI señalando que "la "carrera" tiene el peligro de transformarse, como sucede para todos los empleados, en el gusanillo siempre presente en el subconsciente del magistrado; gusanillo que llega a transformarse en una obsesión en los períodos críticos de su vida, en los que está próximo a alcanzar la antigüedad necesaria para aspirar al ascenso". ${ }^{14}$ Aquí el juez instrumentaliza el proceso como un medio para beneficiarse porque la organización lo incentiva y, por lo mismo, se requiere ir hacía un diseño en que, como dice FerRajoli, el juez no tenga esperanzas de beneficios ni temor de represalias, ${ }^{15}{ }^{16}{ }_{-}{ }^{17}$ esto es, sea imparcial. ${ }^{18}$

${ }^{12}$ Alejandro NiETo, refiriéndose el sistema judicial español, señala que "de lo que hoy se trata es de que los juzgados y salas en los que se tramitan los asuntos que interesan al Poder sean ocupados por jueces de confianza dispuestos a favorecerle sin que alguien se moleste siquiera en pedírselo". NIETO, Alejandro, El desgobierno judicial, Trotta, Madrid, 2005, p. 166.

${ }^{13}$ Montero Aroca, Juan, Sobre la imparcialidad del juez y la incompatibilidad de funciones procesales, Tirant lo Blanch, Valencia, 1999, p. 118.

${ }^{14}$ Calamandrei, Piero, Proceso y democracia, traducción por Héctor Fix Zamudio, Ediciones Jurídicas Europa - América, Buenos Aires, 1960, p. 100.

${ }^{15}$ Cfr. Ferrajoli, Luigi, "El juez en una sociedad democrática”, Conferencia en el Primer Congreso de la Asociación Costarricense de la Judicatura, Costa Rica, 1997 (traducción de Perfecto Andres I.), p. 9, documento pdf (15 p.), disponible en línea: http://biblioteca.cejamericas.org/bitstream/ handle/2015/1887/eljuezenunasociedemocratica.pdf? sequence=1\&isAllowed=y (fecha de visita: 10 de agosto de 2019).

${ }^{16}$ Respecto a la experiencia chilena resulta notable constatar que Andrés Bello, mucho antes, plasmó las mismas ideas en el periódico El Araucano del año 1837, al señalar: "Ni el temor de una desgracia ni la esperanza de una recompensa, deben jamás entrar en la balanza que pesa los intereses más caros a la sociedad; i los que tienen a su cargo esta importante regulación deben hallar en el código político una garantía que los ponga a cubierto de las consecuencias que traiga sobre ellos cualquier paso que no sea una infracción de lei en el ejercicio de su ministerio". Bello, Andrés, Obras Completas de don Andrés Bello, Opúsculos Jurídicos, Volumen IX, Impreso por Pedro G. Ramírez Bello, Santiago, 1881-1883, p. 218.

${ }^{17} \mathrm{El}$ recurso al beneficio puede incluso ser más útil para afectar la imparcialidad y la independencia judicial que el castigo porque, como señala Manuel de la Plaza NAVARRo, "el ascenso es más peligroso que el poder de destitución, acaso porque es más fácil y acaso más cómodo, favorecer al amigo con la promoción que vejar al enemigo con la separación del puesto". PlazA, Manuel, Las garantías de la independencia judicial, Gráfica Clemares, Madrid, 1954, p. 20.

${ }^{18}$ De lo que se trata es de eliminar premios en los cuales exista un margen de discrecionalidad porque 
Acá el análisis es teórico y, por lo mismo, lo que se ha sostenido es que ciertos diseños institucionales del poder judicial crean condiciones para afectar la imparcialidad de judicial. No es objeto de este estudio si en la realidad los jueces se comportan o no de manera imparcial e independiente, puesto que en una dictadura igualmente los jueces pueden, en los hechos, actuar conforme a su deber de aplicar el derecho por las razones que este le suministra, ${ }^{19}$ en tanto que, del mismo modo, en un estado de derecho ideal pueden los jueces no cumplir con ese deber. Como de forma clara expresa Montero Aroca: "las garantías de la independencia se resuelven en posibilitar a cada juez el ser independiente, pero no aseguran que lo sea efectivamente en contra de su voluntad". ${ }^{20}$

El establecer cómo operan en la práctica los modelos judiciales requiere un estudio de campo diverso al que aquí se efectúa. No obstante, el modelo del juez funcionario ha demostrado ser funcional a los gobiernos autoritarios, los que han mantenido la estructura judicial y esta se ha adaptado a dichos gobiernos, como fue el caso del nazismo o el fascismo. ${ }^{21}$ Chile no ha estado ajeno a lo anterior, prueba de ello es que tras el golpe militar de 1973 la junta militar mantuvo al poder judicial y este, salvo casos excepcionales, no efectuó una labor de contención frente a la violación de los derechos humanos por parte de la dictadura. ${ }^{22}$

Se ha hecho alusión al modelo de juez funcionario o napoleónico, boca de ley, propio del Estado legislativo, el que debe contraponerse al juez boca

precisamente ese margen puede ser una amenaza a la imparcialidad e independencia judicial, lo cual no obsta que, respecto al desempeño organizacional, se establezcan incentivos objetivos de desempeño que traigan asociado algún beneficio.

${ }^{19}$ Ingo Müller destaca a Lothar Kreyssig, juez del Tribunal de Tutela de Brandenburgo, el que durante la época nazi en Alemania hizo ver los abusos que se estaban cometiendo. Desde un punto de vista simbólico se retiró temprano de su tribunal cuando se descubría un busto de Hitler o, desde el ejercicio de su cargo, denunció que pacientes del hospital local de enfermos mentales eran trasladados secretamente para darles muerte. Cfr. MüLler, Ingo, Los Juristas del Horror. La "justicia" de Hitler: El pasado que Alemania no puede dejar atrás, traducción por Carlos Armando Figueredo, CTUM, Caracas, 2007, 2a reimpresión, p. 268.

${ }^{20}$ Montero Aroca, cit. (n. 13), p. 119.

${ }^{21}$ Perfecto ANDRÉs afirma que este modelo resulta tener una "extraordinaria funcionalidad y capacidad de integración en distintas experiencias autoritarias". Andrés, Perfecto, En torno a la jurisdicción, Editores del Puerto, Buenos Aires, 2007, p. 45

${ }^{22}$ Lisa Hilbink expresa que "el comportamiento de los jueces, bajo el régimen de Pinochet, es atribuible en gran medida a factores institucionales (...) es necesario entender cómo el aparataje institucional fomentó el comportamiento ilegítimo e incluso antidemocrático, a la vez que limitó el desarrollo y la expresión de las perspectivas democrático-liberales". HiLBINK, Lisa, Jueces y política en democracia y dictadura. Lecciones desde Chile, traducción por Felipe Millán Zapata, Flacso, México, 2014, p. 21. 
de la constitución del Estado constitucional. Ello exige ahondar en estas categorías sobre las cuales corresponderá volver al estudiar el Poder Judicial chileno, de modo que a continuación se desarrollarán dichos modelos de jueces y formas de Estado.

\section{Dos modelos de jueces y dos formas de Estado}

Este apartado busca destacar que el Estado legislativo tiene una forma de entender la labor judicial, el juez boca de la ley, que influye en cómo se organiza la jurisdicción, tendiendo a la idea de un juez funcionario, propio del modelo napoleónico francés, que no debiera hacer otra cosa que aplicar literalmente la ley. Luego, ha de considerarse que hoy nos rige un Estado constitucional de derecho, y cómo ello repercute en los deberes del juez, donde por sobre la ley está la Constitución y el juez es boca de esta. Lo expuesto hace necesario el análisis de la organización judicial a la luz de estos dos tipos de Estado, el legislativo y el constitucional, y de dos formas de ver al juez, el funcionario y el desfuncionarizado, ${ }^{23}$ sin que exista entre unos y otros una relación necesariamente causal ni modelos puros, pero sí marcan una clara tendencia. ${ }^{24}$

El Estado legislativo tiene su impulso en el siglo XVIII con los principios de legalidad y de separación del poder en que, como bien señala Perfecto ANDRÉs, se responde a la interrogante si es mejor un gobierno de los hombres o de la ley, inclinándose por esta última alternativa en que el legislador tiene la suprema potestas y, por lo mismo, la ley es válida por el solo hecho de ser tal. ${ }^{25}$ Aquí concurre la omnipresencia de la mayoría que

\footnotetext{
${ }^{23}$ Por juez funcionario se entenderá aquel que pertenece a una estructura organizacional de tipo jerárquica y con carrera funcionaria, en tanto que por juez desfuncionarizado aquel en que no está presente esa dependencia. Se es consciente que la expresión "desfuncionarizado" no existen en el idioma español, pero se emplea porque permite dar cuenta de aquello que se desea expresar. Además, el término no es desconocido en sede judicial: así, el Tribunal Superior de Justicia de Madrid (TSJM) conoció la anulación de la desfuncionarización llevada a cabo por el alcalde de Alcorcón, David Pérez en 2011. V. Sentencias del TSJM n ${ }^{\circ} 416 / 2017$ y n ${ }^{\circ}$ 465/2017.

${ }^{24}$ Sobre la distinción entre Estado legislativo y constitucional, con relación a la jurisdicción y su organización, existen diversos autores que la ponen de relieve, tales como ANDRÉs, cit. (n. 3); BINDER y Ovando, cit. (n. 11); López Guerra, Luis, El poder judicial en el Estado constitucional, Palestra, Lima, 2001; García Pascual, Cristina, Legitimidad democrática y Poder Judicial, Edicions Alfons el Magnanim, Valencia, 1996; y Ferrajoli, cit. (n. 15), entre otros.

${ }^{25}$ Esta misma interrogante e idéntica respuesta se encuentra en Platón y las leyes, y en Aristóteles y la política. Cfr. BobBio, Norberto, El futuro de la democracia, traducción José Fernández Santillán, Fondo de Cultura Económica, México, 1986, pp. 120-121.
} 
se traduce en la supremacía de la ley. ${ }^{26}$ Agrega Ferrajoli que el "estado de derecho moderno nace, con la forma del estado legislativo de derecho, en el momento en que esta instancia alcanza realización histórica, precisamente, con la afirmación del principio de legalidad como criterio exclusivo de identificación del derecho válido y antes aún existente, con independencia de su valoración como justo", ${ }^{27}$

Es frecuente que un Estado Legislativo se aproxime a un juez funcionario o napoleónico, esto es, sometido a una organización jerárquica que lo constriñe a una carrera funcionaria al igual que cualquier funcionario público. Perfecto AndRÉs señala que los rasgos característicos del diseño napoleónico son bien conocidos, entre los cuales cabe mencionar integración subordinada al ejecutivo; gobierno de la justicia desde un ministerio; cooptación política de la cúspide judicial; organización jerarquizada y en que la carrera funcionaria depende de la aceptación de los criterios del vértice judicial político; interferencia de la jerarquía judicial en lo jurisdiccional; $\mathrm{y}$, falta de independencia interna y externa, entre otros. ${ }^{28}$

El Estado constitucional, como acertadamente plantea ATIENZA, no se trata del simple hecho que un Estado tenga Constitución, sino que a su respecto deben darse tres exigencias, a saber: a) una distribución formal del poder entre los diversos órganos estatales; b) la existencia de derechos fundamentales que se irradian a todo el ordenamiento jurídico, condicionando la aplicación del derecho; $\mathrm{y}, \mathrm{c})$ mecanismos de control de constitucionalidad de las leyes. ${ }^{29}{ }^{30}$

En el Estado constitucional la jurisdicción se acerca a un juez guardián de promesas ${ }^{31}$ establecidas en la Constitución, pero ello no quita

\footnotetext{
${ }^{26}$ Cfr. ANDRÉs, cit. (n. 3), pp. 119-121.

${ }^{27}$ Ferrajoli, Luigi, "Pasado y futuro del Estado de derecho", Revista Internacional de Filosofía Política, $2001, n^{\circ} 17$, pp. 31-45, p. 32.

${ }^{28}$ Cfr. ANDRÉs, cit. (n. 10), p. 62.

${ }^{29}$ Cfr. Atienza, Manuel, "El derecho como argumentación”, en Atienza, M.; Ferrajoli, L., Jurisdicción y Argumentación en el Estado de Derecho, Ed. Instituto de Investigaciones Jurídicas, UNAM, México, 2005, p. 11.

${ }^{30}$ Atienza profundiza estas ideas señalando que "como consecuencia, el poder del legislador (y el de cualquier órgano estatal) es un poder limitado y que tiene que justificarse en forma mucho más exigente. No basta con la referencia a la autoridad (al órgano competente) y a ciertos procedimientos, sino que se requiere también (siempre) un control en cuanto al contenido. El Estado constitucional supone así un incremento en cuanto a la tarea justificativa de los órganos públicos y, por tanto, una mayor demanda de argumentación jurídica (que la requerida por el Estado liberal — legislativo- de derecho)". AtienZa, cit. (n. 29), p. 11.

${ }^{31}$ Está nomenclatura está tomada de Garapón, para quien "El juez — sea el de Nuremberg, sean más
} 
que, como en Chile, rija un Estado Constitucional con jueces funcionarios. Además, no puede perderse de vista que no existen modelos puros: nunca una juez ha sido exclusivamente funcionario, boca de la ley, ni solo guardián de promesas. Sostener un modelo puro, en uno u otro sentido, sería una caricatura y, a la vez, una simplificación irreconciliable con la realidad. ${ }^{32}$ No obstante, el proteger una promesa supone tener claridad respecto del contenido de esta, lo cual es, a lo menos, dificultoso por el carácter abierto de los derechos y garantías constitucionales, de modo que sin desconocer el carácter de custodio del juez resulta más apropiado sostener que su función es ser boca de la Constitución, en los sentidos que Atienza asigna al estado constitucional. Siendo esta la nomenclatura que se utilizará en adelante.

El concepto moderno de jurisdicción viene de la mano de MONTESQUIEU y su idea de separar el poder, lo cual supone integrar dentro del concepto de jurisdicción la exigencia de independencia judicial, debido a que, si el poder judicial está separado de los otros poderes, requiere actuar independientemente. De lo contrario, se mantendría la concentración del poder y la posibilidad de un gobierno despótico. Esto se da en el contexto del origen de un Estado legislativo, donde la ley era la máxima representación de la voluntad popular y por sobre esta no existía ninguna otra manifestación. Ello, en lo judicial, significaba que la independencia judicial es entendida como sujeción a la ley, y a los jueces se les ve como meros aplicadores de esta, es decir, como "la boca que pronuncia las palabras de la ley, seres inanimados que no pueden mitigar la fuerza y el rigor de la ley misma". ${ }^{3}$

Montesquieu es contrario a la idea de una profesionalización de la judicatura, en tanto expresa que el "poder de juzgar no debe confiarse a un tribunal, sino ser ejercido por personas sacadas del cuerpo del pueblo en ciertas épocas del año y de la manera que prescribe la ley, para formar

modestamente nuestros pequeños jueces de barrio - sigue ahí para recordarle a la humanidad, a la nación o al simple ciudadano las promesas que se hizo a sí misma, empezando por la primera de ellas, la promesa de la vida y de la dignidad. Los jueces guardan estas promesas, pero no las atan: son sus testigos, sus garantes y sus guardianes. Les han sido transmitidas, ellos las han escuchado y las recuerdan, llegado el caso, a los mismos que se las habían confiado. ¿Cómo cabría reprochárselo?” Garapón, Antoine, Juez y democracia, Editorial Flor del Viento, Barcelona, 1997, p. 284.

${ }^{32}$ Perfecto ANDRÉs sostiene que la "imagen del juez 'boca de ley', operador neutro, ha sido siempre una ficción y no precisamente inocente". ANDRÉs, Perfecto, "Poder judicial y juez en el Estado constitucional de derecho. El sistema del Consejo", en: Andrés, P. (dir.), La experiencia jurisdiccional: Del Estado legislativo de derecho al Estado constitucional de derecho, Consejo General del Poder Judicial, Madrid, 1999, p. 23.

33 Montesquieu, El espíritu de las leyes, Librería General de Victoriano Suárez, Madrid, 1906, T. I, p. 237. 
un tribunal que sólo dure el tiempo que exija la necesidad". ${ }^{34}$ A la vez, se inclinaba por una justicia estamental para evitar que prejuicios pudieran terminar perjudicando al justiciable, razón por la cual es "menester también que los jueces sean de la condición del acusado o sus pares, para que no pueda recelar que ha caído en manos de personas dispuestas á hacerle violencia". ${ }^{35}$

Los revolucionarios franceses tempranamente, en la Declaración de los Derechos del Hombre y el Ciudadano de 1789, expresaban que "toda sociedad en la cual la garantía de los derechos no está asegurada, ni determinada la separación de los poderes, carece de Constitución". Dentro de sus primeras medidas estuvo la eliminación de los "parlaments", tribunales provinciales que ejercían la jurisdicción real, por ser considerados como conservadores, contrarrevolucionarios, de origen venal y hereditario. ${ }^{36} \mathrm{Se}$ abocaron a la creación de una nueva organización judicial que fuera reflejo de los ideales de la revolución, en especial, de una justicia del pueblo y para el pueblo. Lo anterior, dio origen a la ley sobre organización judicial de agosto de $1790,{ }^{37}$ de la cual cabe destacar los siguientes rasgos: los jueces ya no son remunerados por las partes, sino que por el Estado, siendo gratuita la justicia; se eliminan privilegios y tribunales especiales; los cargos judiciales no se pueden comprar ni heredar; la elección periódica de los jueces; los jueces no pueden interpretar la ley; y, el establecimiento del derecho al recurso, entre otras características.

La ley sobre organización judicial, referida precedentemente, plantea una férrea separación del poder, estableciendo que "las funciones judiciales son distintas y siempre quedan separadas de las funciones administrativas" como mecanismo de evitar interferencias del poder judicial en el poder ejecutivo, a la vez que los jueces no podían suspender o impedir la ejecución

\footnotetext{
${ }^{34}$ Montesquieu, cit. (n. 33), p. 229.

${ }^{35}$ Montesquieu, cit. (n. 33), p. 230.

${ }^{36}$ Un ejemplo paradigmático es el del propio MonTESQuieu que de su tío hereda la presidencia del Parlamento de Burdeos, cargo que a la postre terminaría vendiendo. Cfr. Lousada, José; Ron Latas, Pedro, La independencia Judicial, Dykinson, Madrid, 2015, p. 15.

${ }^{37}$ Jacques Thouret en su discurso de defensa de esta ley, en nombre de la comisión redactora, explicaba que el mayor abuso que corrompió al poder judicial es que se encontraba capturado patrimonialmente y la justicia era administrada en nombre del poder económico, adquiriéndose por herencia o compra el derecho a juzgar a los conciudadanos, los que a su vez debían pagar a los jueces para obtener un acto de justicia. También menciona como abuso la circunstancia que existiera incompatibilidad de funciones en cuanto a que los jueces, llamados a ejecutar las leyes, no podían revisarlas. Cfr. FURET, François; Halévi, Ran, La Monarchie Republicaine, Fallard, París, 1996, pp. 473 y 474.
} 
los actos del legislativo y en caso de que estimaren que la ley requería una interpretación, debían remitírsela a este último. Dicha ley fue complementada por otra de diciembre de 1790, que crea un Tribunal de Casación, dentro del legislativo, para conocer de estas consultas interpretativas en lo que se conoce como el "référé législatif", ${ }^{38}$ el que fuera suprimido por el artículo 4 del Código Civil francés de 1804, al establecer el principio de inexcusabilidad y la prohibición de fallar non liquet, bajo sanción de denegación de justicia.

El modelo francés cambiaría con la llegada de Napoleón ${ }^{39}$ al poder y su golpe de Estado del año 1799, donde los jueces dejan de ser elegidos popularmente y se crea un sistema de carrera funcionaria ligada al ejecutivo, de tipo burocrático. En este sentido, el Senadoconsulto orgánico de la Constitución del 16 de Termidor del año X (4 de agosto de 1802), en sus artículos 78 a 85, establece al ministro de justicia como el juez superior y que, por lo mismo, preside el tribunal de casación y los de apelación cuando el gobierno lo estime conveniente. También vigila y llama la atención a los jueces de paz. A través del tribunal de casación puede censurar y disciplinar a los tribunales de apelación y criminales, suspender a los jueces por causa grave o llamarlos a rendir cuentas sobre su conducta. Los tribunales de apelación tienen derecho de vigilancia sobre los tribunales civiles de su jurisdicción, y los tribunales civiles, sobre los jueces de paz de su distrito. El gobierno tiene un comisario en el Tribunal de casación y este a su vez vigila a los comisarios de los otros tribunales. De esta forma nace el modelo napoleónico de juez funcionario donde la organización judicial se asemeja a una estructura militar en que existe un férreo control desde la jerarquía hacia las bases. ${ }^{40}$

El diseño napoleónico construye un poder judicial jerárquico y con clara dependencia del ejecutivo, de modo que a este le basta con controlar la cúspide de aquel para influir a todos los jueces, los cuales, al ser funcionarios dependientes, no pueden contrarrestar los abusos de poder. Es por lo que este modelo, como ya se ha sostenido previamente, ha demostrado ser funcional

\footnotetext{
${ }^{38}$ Todas estas ideas luego son recogidas por la Constitución francesa de 1791. A lo cual cabe destacar que se otorgan garantías a los jueces por cuanto, conforme al artículo 2 del capítulo $5^{\circ}$, título $3^{\circ}$, "no podrán ser destituidos, salvo prevaricación debidamente juzgada, ni suspendidos, salvo acusación admitida".

${ }^{39}$ Como observa Grossi la codificación napoleónica "es el resultado final de un largo itinerario histórico en el que el derecho llega a identificarse con la ley". Grossi, Paolo, Mitología jurídica de la modernidad, traducción Manuel Martínez Neira, Trotta, Madrid, 2003, p. 74.

${ }^{40}$ Esta reconstrucción puede ser confrontada en ANDRÉs, cit. (n. 3), pp. 56-59; LousADA y Ron LaTAS, cit. (n. 36), pp. 21-23; y GARCíA PASCUAL, cit. (n. 24), pp. 111-113, entre otros.
} 
a los gobiernos autoritarios, los que han mantenido la estructura judicial y esta se ha adaptado a dichos gobiernos.

Cabe preguntarse cómo los revolucionarios franceses, que propugnaban la separación del poder, pueden haber terminado aceptando el modelo de juez funcionario dependiente del ejecutivo que ideara Napoleón. La respuesta es que entendieron al juez como la boca de la ley, un mero aplicador de esta, y por ello la independencia judicial no es otra cosa que la sujeción a la ley. Así, para saber si el juez había resuelto de manera independiente o no bastaba con saber si cumplió o no con ley, sin perjuicio que es una simplificación porque no se desconocía que pudieran presentarse problemas interpretativos en torno a la ley. No obstante, esto en nada alteró el diseño institucional de tipo funcionario que se construyó. La clave está en entender qué es lo que se les pide a los jueces: si solo se les requiere que apliquen la ley no se necesita de una organización de la jurisdicción que los dote de grandes garantías de imparcialidad e independencia, en la medida que al ser un mero aplicador de la ley disminuyen las posibilidades de tener que enfrentarse a algún otro poder estatal.

Un contrapunto sincrónico a la experiencia francesa lo representa Estados Unidos de Norte América, que también en su Constitución 1788 consagra la idea de separación del poder, pero con una comprensión distinta. A diferencia de los franceses, no ven una separación rígida del poder, sino que comprenden la existencia de una colaboración ${ }^{41} \mathrm{y}$, especialmente, no se centran en la idea de MonTesquieu del juez boca de la ley, sino en que por la disposición de las cosas el poder frene al poder, esto es, en un sistema de pesos y contrapesos donde la base del sistema es la supremacía constitucional. Los fundadores tenían claridad respecto a las ideas planteadas precedentemente: prueba de ellos es que HamiLton, en El Federalista, LXXVIII, expresa que: "no es admisible suponer que la Constitución haya podido tener la intención de facultar a los representantes del pueblo para sustituir su voluntad a la de sus electores. Es mucho más racional entender que los tribunales han sido concebidos como un cuerpo intermedio entre el pueblo y la legislatura, con la finalidad, entre otras varias, de mantener a esta última dentro de los limites asignados a su autoridad. La interpretación de las leyes es propia y peculiarmente de la incumbencia

\footnotetext{
${ }^{41}$ Madison, en El Federalista, un 19 de febrero de 1788, refiriéndose al control de poderes, expresa esta idea al señalar, con relación a la separación del poder planteada por MONTESQUIEU, que "no exige que los departamentos legislativo, ejecutivo y judicial estén absolutamente aislados unos de otros".
} 
de los tribunales. Una Constitución es de hecho una ley fundamental y así debe ser considerada por los jueces", ${ }^{42}$

Lo cual desembocaría, a partir del caso Marbury v/s Madison (1803), en un control difuso de la Constitución, donde cualquier juez puede establecer la inconstitucionalidad de una ley.

Es claramente advertible que si el juez, además de aplicar la ley, es un freno al poder, requiere que la organización de la jurisdicción dé cuenta de ello porque el juez está expuesto a enfrentarse a órganos públicos que exceden o abusan de sus atribuciones, y que estos traten de influir en sus decisiones, de modo que debe considerarse una independencia judicial más amplia, dejando atrás la idea del juez funcionario por uno desfuncionarizado. Esto lo entendieron rápidamente en Estados Unidos, tal como lo señala el mismo Hamilton, "el departamento judicial es, sin comparación, el más débil de los tres departamentos del poder; que nunca podrá atacar con éxito a ninguno de los otros dos, y que son precisas toda suerte de precauciones para capacitarlo a fin de que pueda defenderse de los ataques de aquéllos". ${ }^{43}$ Este diseño contempla que el presidente, con aprobación del senado, nombre a los miembros del Tribunal Supremo; que los jueces permanecen en sus cargos mientras tengan buen comportamiento, salvo juicio político; $y$, que los jueces no puedan ver disminuida sus remuneraciones. ${ }^{44} \mathrm{El}$ esquema norteamericano no contempla una carrera funcionara y los jueces son inamovibles e irresponsables, salvo un juicio político, de modo que así se les garantiza una amplia independencia.

La experiencia de Estados Unidos pone de relieve que a los jueces se les puede exigir algo más que solo aplicar la ley. En efecto, tienen un papel de garantes de los derechos y cumplen un rol de contención frente a los posibles desbordes del poder, llegando incluso a realizar un control difuso de constitucionalidad de la ley. Luego, esas mayores exigencias reclaman profundizar las garantías para un ejercicio independiente de la jurisdicción. Claramente el grado de exposición de un juez mero aplicador de la ley es menor a la de aquel que, en resguardo de un derecho constitucional, impide o frena la actuación de un órgano público.

\footnotetext{
${ }^{42}$ Hamilton, Alexander, "El federalista: Ensayo LXXVIII", en Hamilton, A.; Madison, J.; Jay, J., El federalista, Fondo de Cultura Económica, México, 1982, pp. 330-336.

${ }^{43}$ Hamilton, cit. (n. 42).

${ }^{44}$ Aquí se ve una clara influencia del Acta de Establecimiento inglesa de 1701, donde se consagraban las garantías de inamovilidad y de intangibilidad de las remuneraciones de los jueces.
} 
En este punto surge la inquietud de cómo es posible que Francia y Estados Unidos, bajo la influencia de Montesquieu, hayan llegado tener visiones distintas sobre la separación del poder y de la organización de la jurisdicción. La respuesta se encuentra en que, como bien observa TROPER, el principio de separación de poderes tiene un carácter polisémico ${ }^{45}{ }_{-}^{46} \mathrm{y}$ de ahí que en Estados Unidos se quedarán con el sentido de que el poder debe frenar al poder, sistema de pesos y contrapesos, mientras que en Francia se entendió la necesidad de respetar la supremacía de la ley.

Aquí se sigue a GuASTINI, cuando señala que la expresión separación de poderes tiene dos significados en torno al vocablo poder, esto es, como función o como órgano del Estado que ejerce la función, y de ahí que se puede estar separando la función o bien los órganos que ejercen esa función. Cuando se habla de separación de poderes lo que se está haciendo es separar la función en funciones ejecutiva, legislativa y judicial, lo cual supone especialización de las funciones e independencia reciproca de los órganos. En tanto que la división del poder se verifica cuando existe un sistema de frenos y contrapesos donde el poder frena el poder, de modo que no son necesarias la especialidad e independencia del otro modelo. ${ }^{47}$ Así lo que ha ocurrido es que en Estado Unidos se siguió la doctrina de la división del poder, mientras que en Francia se buscó la de separación del poder, pero sin respetar la independencia del poder judicial al adoptar una organización del tipo juez funcionario.

En el mundo del civil law caló hondo el Estado legislativo y la organización de la jurisdicción del tipo juez funcionario. ${ }^{48}$ No obstante, paulatinamente se comienza a requerir de los jueces algo más que ser la boca de la ley y, en ese sentido, se les ve como un reducto en el cual se pueden exigir derechos. En un primer momento, la irrupción de los derechos sociales, tal como ocurre con la Constitución mexicana de 1917 y la alemana de 1919, comienzan a cambiar la mirada que sobre los jueces se tiene, en la medida

\footnotetext{
${ }^{45}$ Cfr. Troper, Michel, "La Ve République et la séparation des pouvoirs", Droits - Revue Française de Théorie, de Philosophie et de culture juridique (Paris), 2006, I, n 43, pp. 33-44.

${ }^{46}$ Barberis nos dice que en MonTESQuiEu "no se encuentra solo una tesis sobre la separación de poderes". BARBERIS, Mauro, Ética para juristas, traducción Álvaro Núñez Vaquero, Trotta, Madrid, 2008, p. 141.

${ }^{47}$ Guastini, Riccardo, Estudios de teoría constitucional, Fontamara, México, 2001, pp. 64-67.

${ }^{48}$ Perfecto ANDRÉs refiere que el "sistema napoleónico de organización judicial hizo fortuna en la Europa continental", lo que, para Italia, producida la unificación, se vio reflejado en el real decreto 2626/1865, el que toma el modelo adoptado previamente por el Reino de Cerdeña. Respecto de España se plasmó a través de la Ley provisional sobre Organización del Poder Judicial de 1870. Cfr. ANDRÉs, cit. (n. 3), pp. 59-60.
} 
que a través de estos se podía exigir al Estado determinadas prestaciones sociales. La mayor transformación se produce como un fenómeno de postguerra, dado que, las constituciones se mostraron incapaces de frenar los abusos del poder, y ello exigió la incorporación de derechos fundamentales a estas y su respectiva garantía a través de los tribunales, lo que cambiaría para siempre la forma de ver la labor de los jueces. ${ }^{49}$

La visión crítica del juez boca de la ley no es algo nuevo, debido que de antaño ha habido voces que se alzaron frente la idea de la aplicación mecánica de la ley por parte de los jueces. GÉNY en 1899, con su libro "Método de Interpretación y Fuentes en Derecho Privado Positivo", plantea que la aplicación mecánica de la ley se trata de una falsedad, en la medida que:

"aun suponiéndola completa y perfecta, no puede la ley por sí sola contener todos los mandatos para satisfacer las necesidades tan concretas de la vida jurídica. Entre estas necesidades tan complejas, tan variadas, tan movibles, y la fórmula rígida del texto legal, hace falta un intermediario que pueda y sepa adaptar esa fórmula a las situaciones y circunstancias para las cuales está escrita. Este intermediario es precisamente el interprete del derecho, y particularmente, en los litigios concretos, el juez". ${ }^{50}$

Concluyendo que la "ley escrita, por ejemplo, sobre la cual nuestra ciencia jurídica positiva pretende hoy edificar todo un sistema, no puede ser tenida por otra cosa que una información muy limitada del derecho". ${ }^{51}$

Si bien, como se expreso, hubo cuestionamientos al juez boca de ley, el cambio de paradigma vino de la mano del nacimiento del Estado constitucional de derecho, donde la Constitución ha dejado de ser un mero catálogo de disposiciones programáticas sin relevancia jurídico-práctico para las personas, ${ }^{52}$ sino que por el contrario, todo el ordenamiento jurídico debe ser construido e interpretado desde la Carta Fundamental, especialmente

\footnotetext{
${ }^{49}$ Perfecto ANDRÉs sostiene que "no es casualidad que el nuevo tipo de legalidad resultante del vigente constitucionalismo se viera acompañado de un nuevo diseño en tema de gobierno judicial y de un también nuevo y acusado patrón de exigencia en materia de independencia”. ANDRÉs, cit. (n. 32), p. 24.

${ }^{50}$ GÉnY, François, Método de interpretación y fuentes en derecho privado positivo, Ediciones Olejnik, Argentina, 2018, p. 159.

${ }^{51}$ Geny, cit. (n. 49), p. 457.

${ }^{52}$ Cfr. Domínguez Águila, Ramón, "La constitucionalización del derecho", en Navarro, E. (ed.), 20 años de la Constitución Chilena: 1981-2001, Ed. Jurídica ConoSur, Santiago, 2001, p. 37.
} 
respecto de los derechos y garantías establecidos por ella, para resguardar su supremacía. La transformación es inmensa, ya no se discute el margen de interpretación de la ley por parte del juez, sino que se va más lejos, esto es, que el juez debe aplicar la Constitución por sobre la ley, en circunstancias que aquella, a diferencia de esta, más que establecer reglas instaura principios cuya defensa corresponde a los jueces.

Se ha desembocado en que a los magistrados les ha sido entregado un papel de garante de los derechos fundamentales, constitucionalmente establecidos, mediante el expediente de los amparos de derechos y el control de que toda autoridad se rija por los mandatos constitucionales. ${ }^{53} \mathrm{El} \mathrm{juez} \mathrm{del}$ Estado constitucional no es la boca de la ley, sino que boca de la Constitución, especialmente respecto del respeto a los derechos fundamentales y de control al poder.

En el Estado constitucional la última palabra no la tiene el legislador porque sobre la ley está la Constitución y las promesas que esta realiza, inundando todo el ordenamiento jurídico $y$, en especial, a los jueces que deben interpretar la ley desde y conforme a la Carta Fundamental. De ahí otra función para los jueces que supone un mayor rango de libertad en el ejercicio de la jurisdicción, puesto que los derechos constitucionales son establecidos, a diferencia de la ley, como principios y no en la forma de una regla, lo cual supone la necesidad del juez de dotarlos de contenido. ZAGREBELSKY, respecto del tránsito del Estado legislativo al constitucional, nos dice que "en síntesis: el legislador debe resignarse a ver sus leyes tratadas como "partes" del derecho, y no como "todo el derecho" (...) los jueces no son los señores del derecho en el mismo sentido en que lo era el legislador en el pasado siglo. Son más exactamente los garantes de la complejidad estructural del derecho en el Estado constitucional, es decir, los garantes de la necesaria y dúctil coexistencia entre ley, derechos y justicia". ${ }^{54}$

${ }^{53}$ Tal como afirma Bordalí: "con la Ley fundamental de Bonn -y también con la mayoría de las Constituciones europeas de la posguerra-, los derechos fundamentales pasaron a ser derechos directamente aplicables, no ya válidos en el ámbito de la ley, sino que, por el contrario, las leyes pasaron a ser válidas en el ámbito de los derechos fundamentales. Éstos pasan a ser concebidos como espacios mínimos reservados a la actuación de las personas, espacios que deben necesariamente ser respetados por todos, incluyendo, por supuesto, también al Estado; respeto que se puede hacer valer ante el órgano jurisdiccional, como órgano de tutela última y necesaria de los derechos de las personas, aun frente a la ley". Bordalí Salamanca, Andrés, "Independencia y responsabilidad de los jueces", Revista de Derecho (Valdivia), 2003, Vol. 14 (jul), p. 66.

${ }^{54}$ Zagrebelsky, Gustavo, El derecho dúctil. Ley, derechos, justicia, traducción Marina Gascón, Trotta, Madrid, 2011, p. 153. 
Si el juez es boca de la constitución, se produce una tensión con el modelo del juez funcionario, dado que se requiere dotarlo de la libertad suficiente para someter todo poder público a la Constitución, cuestión que dicho modelo no realiza por su dependencia administrativa que lo somete a una carrera funcionaria. Además, respondiendo a la objeción democrática, autores como FeRRAJOLI han planteado que las constituciones establecen una democracia sustancial o de principios en oposición a la democracia mayoritaria, legitimándose a los jueces como garantes de derechos fundamentales $\mathrm{y}$, por lo mismo, ostentan una legitimación democrática a ese respecto. ${ }^{55}$ Esto requiere mayores grados de independencia interna y externa, ${ }^{56}$ intentándose diversas fórmulas en tal sentido, las que en todo caso atenúan o suprimen la idea del juez funcionario, y que normalmente van de la mano de la creación de consejos de la magistratura, cuya función es velar por la independencia judicial de los jueces.

La dificultad del modelo de juez del Estado constitucional de derecho es que, si bien requiere de una vasta independencia del juez, como exigencia de las amplias funciones que el modelo le confiere, por otra parte trae aparejado el riesgo que el juez abuse de esa independencia y se verifique un activismo judicial en su peor versión, esto es, que el juez no aplique el derecho por las razones que este le suministra, sino que resuelva conforme a sus creencias personales y, de esta forma, invada atribuciones de otros poderes estatales, trastocando la distribución del poder dentro del Estado al reemplazar la voluntad del poder ejecutivo o del legislativo por la suya. Esto se agrava si se considera que el poder judicial, respecto de los otros poderes estatales tiene un déficit de legitimidad democrática representativa, en la medida que los jueces no son elegidos directamente y, no obstante, su opinión prevalece por sobre el ejecutivo y el legislativo. Esta problemática debe ser tenida en cuenta cuando se analiza la independencia judicial dentro del Estado constitucional de derecho, lo cual corresponde a un trabajo diverso al que aquí se realiza. ${ }^{57}$

A manera de colofón, expresar que la revisión que aquí se ha realizado permite sostener que el modelo de un juez funcionario se adapta al Estado

\footnotetext{
${ }^{55}$ Cfr. Ferrajoli, Luigi, Derechos y Garantías. La ley del más débil, Trotta, Madrid, 2002, p. 27.

${ }^{56}$ Cfr. Andrés, cit. (n. 3), pp. 119-138.

${ }^{57}$ En nuestro país ha habido voces que han levantado críticas de un creciente activismo judicial, tal es el caso de José Francisco García y Sergio Verdugo. Cfr. García, José; Verdugo, Sergio, ¿Hacia el Gobierno de los Jueces? Activismo Judicial en Chile, Libertad y Desarrollo, Santiago, 2014.
} 
legislativo porque a estos se les concibe como meros aplicadores de la ley; luego dicho diseño presenta dificultades en el Estado constitucional porque el juez no solo aplica la ley, sino que también la Constitución y es un garante de los derechos fundamentales, de modo que el juez requiere de mayores grados de independencia, cuestión que no hace el modelo napoleónico. De lo dicho resulta que organizar la jurisdicción supone la comprensión del Estado que rige y de lo que se espera del juez.

\section{EL PODER JUDICIAL CHILENO}

\section{La tensión entre el juez del Estado Legislativo y el juez del Estado Constitucional.}

Aquí se pretende, por una parte, poner de relieve que la organización de la jurisdicción en Chile responde a un esquema colonial que fue mantenido en la República, la que adscribe al Estado legislativo y al juez boca de la ley, sin que se mantengan actualmente las razones que sustentaron la existencia del modelo. Luego se busca evidenciar que hoy nos rige un Estado constitucional donde el juez es boca de la Constitución, especialmente en lo referido al resguardo de derechos fundamentales, lo cual se dificulta porque el diseño institucional del poder judicial chileno opera como una camisa de fuerza para el juez. En definitiva, el punto a destacar es que el juez, en lo organizacional, se rige por el esquema del Estado legislativo donde es boca de ley, en tanto que en lo jurisdiccional obedece al Estado constitucional, que le exige ser boca de la Constitución.

El Poder Judicial chileno presenta un modelo organizativo heredado de la época colonial que, en lo substancial, mantiene una estructura jerárquica y piramidal, colocando en la cúspide a la Corte Suprema. En la República se mantuvo el modelo regio con la única diferencia que el monarca es remplazado por la Corte Suprema o el Jefe de Estado, según sea el caso. Desde el artículo 148 de la Constitución de $1823^{58}$ la Corte Suprema ha tenido la superintendencia de todos los tribunales de la República que antes correspondía a la real audiencia. Bravo LiRa sostiene que lo "único que

\footnotetext{
${ }^{58}$ El artículo 148 de la Constitución de 1823 disponía: "Tiene la Suprema Corte la superintendencia directiva, correccional, económica y moral ministerial, sobre los tribunales y juzgados de la Nación. Tiene también la de la policía criminal conforme al reglamento que se formará sobre estas atribuciones".
} 
subsistió de la Constitución de 1823 fue la reestructuración de la Judicatura ordinaria en términos que persisten hasta hoy". ${ }^{59}$ En el mismo sentido, BeCERRa manifiesta que la "Corte Suprema observa un diseño institucional que puede trazarse desde épocas coloniales hasta nuestros días básicamente sin modificaciones sustanciales (...) el diseño institucional actual de la Corte no presenta mayores diferencias con respecto a la Corte Suprema del siglo XIX y el sistema judicial en que ella se inserta, siendo tal sistema tributario de una teoría política de cuño monárquico y pre republicano". ${ }^{60}$

Con base a lo anterior, Aldunate Lizana afirma que existe una constitución monárquica del Poder Judicial en referencia a que "nuestro sistema judicial presenta rasgos de la judicatura monárquica existente a la fecha del advenimiento de la República". ${ }^{11}$ Cabe preguntarse: ¿por qué la Corona adopta dicha estructura? La respuesta es que en 1768 el rey Carlos III prohibió motivar las resoluciones judiciales, razón por la cual deja de existir un control objetivo de las sentencias y este pasa a ser subjetivo, de modo que se exigía un comportamiento ejemplar en el juez porque precisamente ahí recaía su fuente de legitimidad. Este control férreo en el comportamiento de los jueces es el que se ha heredado hasta nuestros días.

En Chile, la Constitución de 1822 incluyó por primera vez el deber de fundamentación de la sentencia, ${ }^{62}$ aunque no pudo ser llevada a la práctica porque a los tres meses fue reemplazada por la Constitución de 1823, la que no contempló dicha exigencia. No obstante, hubo voces que se levantaron frente a este retroceso, entre ellos Andrés BELlo, quien, contra la opinión de los jueces, ${ }^{63}$ sostuvo que "admitir sentencias no fundadas equivale en nuestro concepto a privar a los litigantes de la más preciosa garantía que pueden tener para sujetarse a las decisiones judiciales". ${ }^{64}$ Deber de motivación que reaparece definitivamente por un decreto del presidente José Joaquín Prieto en 1837, dictado en uso de facultades extraordinarias conferidas

\footnotetext{
${ }^{59}$ Bravo Lira, Bernardino, Historia de las instituciones politicas de Chile e Hispanoamérica, Editorial Andrés Bello, Santiago, 1986, p. 178.

${ }^{60}$ Becerra, Pablo, El rol de la Corte Suprema, Der, Santiago, 2017, p. 14.

${ }^{61}$ Aldunate Lizana, Eduardo, "La Constitución Monárquica del Poder Judicial", Revista de Derecho

P. Universidad Católica de Valparaíso, 2001, Vol. 22, p. 193.

${ }^{62} \mathrm{Al}$ efecto su artículo 219 señalaba: "Toda sentencia civil y criminal deberá ser motivada".

${ }^{63}$ Cfr. Ballesteros, Manuel, La Ley de Organización y atribuciones de los tribunales de Chile, Imprenta Nacional, Santiago, 1890, T. I, p. 444.

${ }^{64}$ Bello, Andrés, "Necesidad de fundar las sentencias" (1834), en periódico El Araucano, № 197, 20 de junio de 1834.
} 
para hacer frente a la guerra con la confederación peruano-boliviana. ${ }^{65}$ La consolidación de la obligación de fundamentación se verifica con una ley del 12 de septiembre de $1851,{ }^{66}$ sobre el modo de acordar y fundar las sentencias, bajo sanción de nulidad en caso de incumplimiento. ${ }^{67}$

El deber de fundamentación referido se ha mantenido ininterrumpidamente hasta nuestros días, en tanto todos los procedimientos reformados requieren de motivación a través de un razonamiento judicial reproducible, tal cual disponen los artículos 297, 340 y 342, letras c y d, del Código Procesal Penal. En materia laboral, los artículos 456 y 459, números 4 y 5, del Código del Trabajo. En familia, los artículos 32 y 66, números 4 y 5 , de la ley 19.968, que crea los tribunales de familia. La infracción al deber de fundamentación da origen al recurso de nulidad penal o laboral. El Código Procesal Penal establece que dicha infracción es un motivo absoluto de nulidad, según su artículo 374, letra e, caso en el cual el juicio y la sentencia serán siempre anulados. En materia laboral el artículo 478, letra e), primera parte, sanciona con nulidad dicho vicio. En familia procede el recurso de casación en la forma conforme al artículo 67, número 6, letra b, segunda parte, de la ley 19.968. En materia civil el deber de fundamentación se contempla como requisito de la sentencia en el artículo 170, números 4 y 5, del Código de Procedimiento Civil. Su omisión se sanciona con nulidad vía recurso de casación en la forma, conforme al artículo 768, número 5, de dicho Código. Además, en matera civil rige el sistema de la prueba legal tasada, de modo

${ }^{65} \mathrm{Cfr}$. Hanisch, Hugo, "Contribución al estudio del principio y de la práctica de fundamentación de las sentencias en Chile durante el siglo XIX", Revista de Estudios histórico-jurídicos, 1982, VII, pp. $131-173$.

${ }^{66}$ A esta ley hubo resistencia, tal como se señala en las obras completas de Andrés Bello: "Uno de ellos, presidente de la corte suprema, tachó el proyecto de impracticable, por cuanto los jueces no podían sujetarse a sus preceptos, por hallarse agobiados de trabajo; i de inconstitucional, por cuanto no se habían dictado todavía la lei de organización ele los tribunales i la de administración de justicia, determinadas por la constitución de 1833". BELLo, cit. (n. 16), p. 34.

${ }^{67}$ La ley de 1851 sobre el modo de acordar y fundar las sentencias en sus artículos 3 y 5 dispuso:

"Articulo 3. ${ }^{\circ}$ Toda sentencia definitiva o interlocutoria de primera instancia i las revocatorias de las de otro tribunal o juzgado, contendrán: $1 .^{\circ} \mathrm{La}$ designación precisa de las partes litigantes. $2 .^{\circ}$ La enunciación breve de las peticiones o acciones deducidas por el demandante, $\mathrm{i}$ de las defensas o excepciones alegadas por el demandado. $3 .^{\circ}$ Los hechos i las disposiciones legales, en defecto de éstas la costumbre que tenga fuerza de lei, i a falta de una $i$ otra, las razones de equidad natural que sirvan de fundamento a la sentencia. $4 .^{\circ}$ La decisión del asunto controvertido. Los tribunales solo podrán sentar como fundamento de sus sentencias aquellos que hubieren obtenido la aprobación de la mayoría".

Art. 5. "La sentencia definitiva que no se hubiere estendido en la forma que prescribe el artículo $3 .^{\circ}$, es nula. El recurso que en este caso se entablare queda sujeto a todas las reglas establecidas por la lei de $1 .^{\circ}$ de Marzo de $1837 ”$. 
que la vulneración de las leyes reguladoras de la prueba puede perseguirse a través del recurso de casación en el fondo por haber infracción de ley en los términos del artículo 767 del Código de Procedimiento Civil.

El establecimiento temprano, en nuestra historia republicana, del deber de motivación de las sentencias entra en pugna con las razones por las que se adoptó la organización monárquica de la jurisdicción, esto es, la falta de esa motivación. Si en la República se acoge la necesidad de fundamentación de las sentencias, cabe preguntarse por qué se mantuvo la organización de tipo monárquico. La respuesta es que se adscribe al Estado legislativo y al juez boca de la ley, en que no resulta extraño una organización funcionarial de la jurisdicción. En efecto, Andrés Bello recordaba que los jueces son esclavos de la ley y, en consecuencia, aunque estos se enfrenten a leyes, en su parecer injustas, no pueden obrar por sobre la ley ni desatenderla porque el gobierno es de las leyes, y no de las opiniones de los magistrados. ${ }^{68}$ Tanto es así que el Código Penal de 1874, vigente hasta el día de hoy, establece, en su artículo $223 \mathrm{~N}^{\circ} 1$, el delito de prevaricación para el caso en que los jueces "a sabiendas fallaren contra ley expresa y vigente en causa criminal o civil". Esto evidencia un legicentrismo y la opción por una teoría formalista de interpretación que entiende como significado correcto el literal. De esta forma el diseño institucional de tipo monárquico del poder judicial ha subsistido hasta nuestros días, manteniendo un control subjetivo de los jueces.

Conforme a lo aquí examinado puede afirmarse que al momento de nuestra independencia regía un esquema monárquico, de diseño jerárquico y dependiente del monarca, que establecía una organización basada en un control subjetivo de los jueces, dado que estos no tenían el deber de fundamentación de sus sentencias. En la república se replicó el diseño jerárquico del poder judicial y se radicó en la Corte Suprema la cúspide de la jerarquía judicial, manteniéndose una organización propia de un control subjetivo pese a que existe el deber de motivación. A su vez, al adoptarse las ideas de un estado legislativo de derecho no fue extraño considerar que la independencia judicial se verificaba con la sujeción del juez a la ley, lo cual se mantiene hasta nuestros días y resulta contradictorio con la circunstancia que el Estado legislativo fue reemplazado por uno constitucional, lo cual deberá ahondarse en lo que viene.

${ }^{68}$ Cfr. Bello, cit. (n. 16), p. 202. 


\section{Organización de la jurisdicción y función jurisdiccional.}

Se tuvo ocasión de establecer que el sintagma "poder judicial" tiene dos sentidos, el jurisdiccional y el organizativo, de modo que corresponde ahora llevar el contenido teórico que se ha revisado al plano del ser, y verificar si dicha distinción es aplicable al Poder Judicial chileno. De establecerse la opción afirmativa surge un nuevo asunto del cual también se debe dar cuenta, es decir, si el ordenamiento jurídico chileno realiza una regulación consistente de lo jurisdiccional y lo organizativo.

La Constitución de 1980 construyó el Poder Judicial chileno sobre la base del régimen tradicional de división de los poderes del Estado en Ejecutivo, Legislativo y Judicial. ${ }^{69}$ Si bien se instituyó al poder judicial con un carácter jerárquico y piramidal, ello no obsta a que cada juez de la República, tanto un ministro de la Corte Suprema como el juez de Tierra del Fuego, está dotado de la misma potestad jurisdiccional y es el poder judicial en sí mismo, pues lo que los diferencia no es la jurisdicción sino que su competencia, dado que todo juez por ser tal puede aplicar el derecho, pero no todos conocen de los mismos asuntos ni de la misma forma.

El artículo 76, inciso primero, de la Constitución ${ }^{70}$ entrega exclusivamente a los tribunales establecidos por la ley, no al conjunto de ellos o a la Corte Suprema, la facultad de conocer de las causas civiles y criminales, de resolverlas y de hacer ejecutar lo juzgado. Como señala Bordalí, "no existe en nuestro ordenamiento constitucional un titular genérico de dicha potestad, al contrario de lo que sucede con el Legislativo y el Ejecutivo, sino que cada uno de los jueces o tribunales está investido en el mismo grado e intensidad de esa potestad". ${ }^{71}$ Luego la misma Constitución erige una organización judicial jerárquica y piramidal al disponer en su artículo 82 , inciso primero, ${ }^{72}$ que la Corte Suprema tiene la superintendencia directiva, correccional y económica

\footnotetext{
${ }^{69}$ Ver actas oficiales de la Comisión de Estudios de la Nueva Constitución, sesión 338, de 8 de marzo de 1978.

${ }^{70}$ Artículo 76, inciso primero, de la Constitución: "La facultad de conocer de las causas civiles y criminales, de resolverlas y de hacer ejecutar lo juzgado, pertenece exclusivamente a los tribunales establecidos por la ley. Ni el presidente de la República ni el Congreso pueden, en caso alguno, ejercer funciones judiciales, avocarse causas pendientes, revisar los fundamentos o contenido de sus resoluciones o hacer revivir procesos fenecidos".

${ }^{71}$ Bordalí, cit. (n. 53), p. 159.

${ }^{72}$ Artículo 82, inciso primero, de la Constitución: "La Corte Suprema tiene la superintendencia directiva, correccional y económica de todos los tribunales de la Nación. Se exceptúan de esta norma el Tribunal Constitucional, el Tribunal Calificador de Elecciones y los tribunales electorales regionales".
} 
de todos los tribunales de la Nación, salvo los ahí exceptuados.

La relación de los artículos 76 y 82 de la Carta Fundamental muestra que, por una parte, el ejercicio de la jurisdicción corresponde a cada juez, pero, por otra, los jueces organizativamente se encuentran subordinados a la Corte Suprema y, debido a ello, es válido sostener que la Constitución reconoce la distinción entre lo jurisdiccional y lo organizativo. No obstante, el articular ambos planos no es tarea fácil porque se le dice al juez que debe ejercer individualmente jurisdicción, pero, al mismo tiempo, se lo somete a una jerarquía organizacional bajo el binomio juez independiente pero funcionario dependiente, lo cual es un contrasentido porque, por un lado, se le pide que solo esté sometido al derecho para resolver los asuntos de los que conoce pero, por otro, se lo sujeta a una jerarquía férrea. Es así como, conforme al artículo 226 del Código Penal, ${ }^{73}$ el juez comete delito prevaricación si no cumple la orden de su superior a menos que se encuentre en los casos de excepción en que se le permite representar la orden, pero que deberá cumplir de haber insistencia, salvando en este caso su responsabilidad y esta recaerá en el superior del cual emanó la orden.

En lo jurisdiccional, la Constitución consagra al Poder Judicial chileno como un poder del Estado. El capítulo VI, lo denomina "poder judicial", prohibiendo que el presidente de la República y el Congreso puedan, en caso alguno, ejercer funciones judiciales, avocarse causas pendientes, revisar los fundamentos o contenido de sus resoluciones o hacer revivir procesos fenecidos, de conformidad al artículo 76, inciso $1^{\circ}$, de la Constitución. No restringe la labor del juez a la mera aplicación de la ley en la medida que la Carta Fundamental es norma jurídica directamente aplicable y está por sobre la ley, de modo que todo poder estatal, incluido el poder legislativo, debe someterse a la Constitución conforme al principio de juridicidad dispuesto

\footnotetext{
${ }^{73}$ El artículo 226 del Código Penal dispone: "En las mismas penas incurrirán cuando no cumplan las órdenes que legamente se les comuniquen por las autoridades superiores competentes, a menos de ser evidentemente contrarias a las leyes, o que haya motivo fundado para dudar de su autenticidad, o que aparezca que se han obtenido por engaño o se tema con razón que de su ejecución resulten graves males que el superior no pudo prever.

En estos casos el tribunal, suspendiendo el cumplimiento de la orden, representará inmediatamente a la autoridad superior las razones de la suspensión, y si ésta insistiere, le dará cumplimiento, libertándose así de responsabilidad, que recaerá sobre el que la mandó cumplir".
} 
en sus artículos $6^{\circ 74}$ y $7^{\circ} . .^{75}$

A los jueces se les entrega la defensa de los derechos fundamentales por vía de las acciones de protección y amparo contempladas en los artículos 20 y 21 de la Constitución, tanto frente al Estado como de particulares, lo que además es reforzado por el deber constitucional de resguardo de los derechos humanos del artículo $5^{\circ}$ de la misma Carta que, entre otras, se manifiesta en la cautela de garantías en materia penal, artículo 10 del Código Procesal Penal, o la tutela laboral del artículo 584 del Código del Trabajo. A su vez, la Carta Fundamental confiere acción a cualquier persona que sea lesionada en sus derechos por la Administración del Estado, de sus organismos o de las municipalidades para reclamar ante los tribunales, en los términos de su artículo 38. También, en resguardo de la supremacía constitucional, la Constitución, en su capítulo VIII, instituye un Tribunal Constitucional. De este modo, en Chile se dan las tres características dadas por ATIENZA para sostener la existencia de un Estado constitucional, esto es: distribución formal del poder entre los diversos órganos estatales; la existencia de derechos fundamentales que se irradian a todo el ordenamiento jurídico, condicionando la aplicación del derecho; $\mathrm{y}$, mecanismos de control de constitucionalidad de las leyes.

La revisión precedente permite sostener que la Constitución de nuestro país distingue en el poder judicial un aspecto organizativo y uno jurisdiccional, pero el problema es que el primero no es garantía del segundo porque mantiene dos modelos de jueces incompatibles. Lo organizativo está construido sobre la base del Estado Legislativo con jueces funcionarios, mientras que lo jurisdiccional se erige sobre las bases del Estado Constitucional. Esto es inconsistente porque, por una parte, se quiere de jueces que más allá de la ley apliquen principios y sean garantes de los derechos fundamentales, pero, por otra parte, para cumplir esas funciones cuentan con una estructura judicial que responde a jueces funcionarios.

\footnotetext{
74 “Artículo $6^{\circ}$.- Los órganos del Estado deben someter su acción a la Constitución y a las normas dictadas conforme a ella, y garantizar el orden institucional de la República.

Los preceptos de esta Constitución obligan tanto a los titulares o integrantes de dichos órganos como a toda persona, institución o grupo.

La infracción de esta norma generará las responsabilidades y sanciones que determine la ley”.

75 “Artículo $7^{\circ}$.- Los órganos del Estado actúan válidamente previa investidura regular de sus integrantes, dentro de su competencia y en la forma que prescriba la ley.

Ninguna magistratura, ninguna persona ni grupo de personas pueden atribuirse, ni aun a pretexto de circunstancias extraordinarias, otra autoridad o derechos que los que expresamente se les hayan conferido en virtud de la Constitución o las leyes.

Todo acto en contravención a este artículo es nulo y originará las responsabilidades y sanciones que la ley señale".
} 


\section{Imparcialidad judicial y organización de la jurisdicción.}

La raíz del problema reside en que el diseño institucional del Poder Judicial chileno radica en la cúspide de la jerarquía judicial tanto el ejercicio de la jurisdicción como del gobierno judicial, habiendo una concentración de funciones a ese respecto. Así la Corte Suprema es el grado jurisdiccional más alto de nuestro sistema y, al mismo tiempo, es el órgano máximo de gobierno judicial, en la medida que tiene la superintendencia direccional, correccional y económica de todos los tribunales de la República, salvo de los constitucionalmente exceptuados. A todo lo anterior, se suman las atribuciones de gobierno en que intervienen los otros poderes estatales, según se dirá.

La organización judicial chilena impone al juez una serie de obstáculos para el ejercicio de la jurisdicción. Entre estas injerencias, desde el aspecto interno, el juez cuando resuelve debe obviar, si es que ello es posible, que quienes revisan sus resoluciones judiciales son también los que lo califican, ${ }^{76}$ inciden en su ascenso, ${ }^{77}$ pueden sancionarlo, trasladarlo o removerlo. ${ }^{78}$ Esta situación se intensifica porque el superior jerárquico al momento de ejercer estas atribuciones lo hace con una alta discrecionalidad y apreciación subjetiva, dado que la organización de la jurisdicción así se lo permite. A manera ilustrativa, el artículo 544, número 4, del Código Orgánico de Tribunales sanciona, en términos amplísimos, al juez que "por irregularidad de su conducta moral o por vicios que les hicieren desmerecer

\footnotetext{
${ }^{76}$ De acuerdo con el artículo 273 del Código Orgánico de Tribunales todos los jueces y ministros de Cortes de Apelaciones son calificados. Los únicos miembros del escalafón primario del poder judicial que no se califican son los ministros de la Corte Suprema. Los jueces son calificados por el pleno de la Corte de Apelaciones a cuyo territorio están adscritos. En tanto que los ministros de Corte de Apelaciones son calificados por el pleno de la Corte Suprema.

${ }_{77}$ De acuerdo con el artículo 78 de la Constitución, los jueces son nombrados por el presidente de la República de una terna que efectúa la Corte de Apelaciones a cuyo territorio corresponde el cargo. Los ministros de Corte de Apelaciones también son nombrados por el presidente de la República, pero de una terna que elabora la Corte Suprema. Finalmente, los ministros de Corte Suprema son nombrados por el presidente de la República, de entre una quina que confecciona la propia Corte Suprema, con aprobación del Senado.

${ }^{78}$ El régimen disciplinario de los jueces está entregado al pleno de la Cortes de Apelaciones, según el artículo 66 del Código Orgánico de Tribunales. Respecto de los ministros de esas Cortes la competencia disciplinaria es del pleno de la Corte Suprema, en los términos del artículo 96 de dicho Código. Las sanciones, conforme al artículo 537 del referido cuerpo normativo, pueden ir desde la amonestación a la suspensión del cargo por cuatro meses con goce de media remuneración. En cuanto a la remoción de jueces o ministro por no tener buen comportamiento, siempre corresponde al pleno de la Corte Suprema de acuerdo con el artículo 80 de la Constitución.
} 
en el concepto público, comprometieren el decoro de su ministerio".

Respecto a los concursos, el Código referido solo brinda reglas generales para la elaboración de las ternas o quinas, según el caso, de entre las cuales se hará la designación del juez o ministro. Por ello un gran número de los oponentes está en condiciones de ser incluidos en dichas ternas o quinas, de modo que se abre la puerta a valoraciones, más allá del mérito, por parte del superior jerárquico. ${ }^{79}$ Lo mismo ocurre con las calificaciones en tanto, conforme al artículo 277 bis del Código Orgánico de Tribunales, deben considerarse por el superior jerárquico los aspectos subjetivos de responsabilidad, capacidad, conocimientos, iniciativa, eficiencia, afán de superación, relaciones humanas y atención al público.

En el ámbito externo, el poder judicial no cuenta con autonomía financiera, los nombramientos de jueces son realizados por el ejecutivo, para el caso de un ministro de la Corte Suprema con participación del Senado, y, además, el presidente de la República tiene supervigilancia sobre el comportamiento de los jueces, ${ }^{80}$ los que, tratándose de ministros, son acusables políticamente. En este plano estas atribuciones quedan entregadas a la discrecionalidad política de los gobernantes del momento. Esto es así porque, como se ha explicado, nuestro sistema en lo organizativo ha mantenido el diseño del juez funcionario, pero dentro de un Estado Constitucional.

El diseño institucional el Poder Judicial chileno reúne las condiciones para afectar la imparcialidad judicial, en la medida que establece un sistema de carrera funcionaria altamente discrecional. Los incentivos y castigos van predeterminando el comportamiento de los jueces en desmedro de la jurisdicción, sin que sea necesario que nadie les pida algo porque el propio sistema se encarga de mostrarles cómo deben actuar para una carrera exitosa

\footnotetext{
${ }^{79}$ Una práctica ampliamente arraigada en Chile es el llamado "besamanos" que se refiere a las audiencias privadas que otorgan los ministros a los oponentes en los respectivos concursos. Dada la opacidad de esta práctica la Asociación Nacional de Magistrados se ha rebelado en contra de ella y, en tal sentido, la Corte Suprema, en antecedentes administrativos 1.112-2015, de 21 de julio de 2015, adhirió a esta preocupación. Dicha Corte dicta el acta 133-2015 en la cual establece audiencias públicas para los concursos y establece, en su artículo $7^{\circ}$, un deber de abstención respecto de audiencias privadas, pero sin que exista sanción alguna a este respecto y ello no obsta que se puedan verificar estos encuentros fuera de tribunales.

${ }^{80}$ El artículo 32 número 13 de la Constitución establece la atribución especial del presidente de la República de: "Velar por la conducta ministerial de los jueces y demás empleados del Poder Judicial y requerir, con tal objeto, a la Corte Suprema para que, si procede, declare su mal comportamiento, o al ministerio público, para que reclame medidas disciplinarias del tribunal competente, o para que, si hubiere mérito bastante, entable la correspondiente acusación".
} 
y evitar el castigo. Esto trae como consecuencia que el objeto del proceso puede no ser indiferente al juez, sino que es el medio para ascender dentro de la organización judicial en desmedro de la imparcialidad judicial.

\section{CONCLUSIONES}

Se ha podido realizar un reconocimiento o anagnórisis en orden a que el diseño institucional del poder judicial puede crear condiciones para afectar la imparcialidad judicial. Cuando ese diseño contempla una carrera funcionaria basada en premios y castigos, con alto grado de discrecionalidad, el objeto del proceso no resulta indiferente al juez porque es el medio a través del cual ganar la carrera funcionaria. Es decir, actúa movido por el interés personal y no por la aplicación del derecho conforme a las razones que el mismo derecho suministra.

El Poder Judicial chileno, en lo organizativo, tiene un origen colonial que se mantuvo en la república. Se establece una estructura jerárquica con un amplio control desde la cúspide a las bases, encuadrándose en un modelo de juez funcionario propio del Estado Legislativo. El juez chileno ingresa a una carrera funcionaria en donde busca los beneficios y, a la vez, evita el castigo para ir ascendiendo en el escalafón judicial. El carácter de funcionario del juez se encuentra en tensión con su función jurisdiccional porque ser imparcial puede tener costos para su carrera.

El Poder Judicial chileno, en lo jurisdiccional, representa al Estado Constitucional en que el juez no solo aplica la ley, sino que también tiene el deber de resguardar los derechos constitucionales en un contexto de supremacía constitucional. Lo cual demanda mayores grados de imparcialidad e independencia judicial porque el juez debe controlar que todo órgano público se sujete a la constitución y a las normas dictadas conforme a esta, de modo que está en disposición de tener que contener al poder y enfrentarse a este. En esta tarea el juez no debe pensar cómo afectará su carrera judicial la decisión que tome porque ello puede volverlo parcial, en la medida que no aplique el derecho y resuelva en función de sus intereses personales.

Es necesario que la organización de la jurisdicción responda al Estado Constitucional en que el diseño institucional del poder judicial se construya como garantía de una jurisdicción imparcial e independiente, en términos que la estructura, siendo subordinada e instrumental, permita el cumplimiento 
de la función jurisdiccional. El diseño institucional del poder judicial debe garantizar jueces imparciales siempre y no hasta que comienzan a serlo.

\section{BIBLIOGRAFÍA CITADA}

\section{a) Doctrina}

Aguiló, Josep, "De nuevo sobre 'Independencia e imparcialidad de los jueces y argumentación jurídica”, Jueces para la democracia, 2003, nº 46.

Aguiló, Josep, "Los deberes internos a la práctica de la jurisdicción. Aplicación del derecho, independencia e imparcialidad", Revista Jurídica de les Illes Balears, 2012, núm. 10.

Aldunate Lizana, Eduardo, "La Constitución Monárquica del Poder Judicial”, Revista de Derecho P. Universidad Católica de Valparaíso, 2001, Vol. 22, pp. 193-207.

Andrés, Perfecto, Cultura constitucional de la jurisdicción, Siglo del Hombre Editores, Universidad EAFIT, Bogotá, 2011.

ANDRÉs, Perfecto, El tercero en discordia, Trotta, Madrid, 2015.

AndrÉs, Perfecto, "Poder judicial y juez en el Estado constitucional de derecho. El sistema del Consejo", en: Andrés, P. (dir.), La experienciajurisdiccional: Del Estado legislativo de derecho al Estado constitucional de derecho, Consejo General del Poder Judicial, Madrid, 1999.

AndRÉs, Perfecto, En torno a la jurisdicción, Editores del Puerto, Buenos Aires, 2007.

AtiEnZA, Manuel, "El derecho como argumentación", en Atienza, M.; Ferrajoli, L., Jurisdicción y Argumentación en el Estado de Derecho, Ed. Instituto de Investigaciones Jurídicas, UNAM, México, 2005.

Atria, Fernando, La forma del derecho, Marcial Pons, Buenos Aires, 2016.

Ballesteros, Manuel, La Ley de Organización y atribuciones de los tribunales de Chile, Imprenta Nacional, Santiago, 1890, T. I.

BARBERIS, Mauro, Ética para juristas, traducción de Álvaro Núñez Vaquero, Trotta, Madrid, 2008.

Becerra, Pablo, El rol de la Corte Suprema, Der, Santiago, 2017.

Bello, Andrés, "Necesidad de fundar las sentencias" (1834), en periódico $E l$ Araucano, No 197, 20 de junio de 1834.

Bello, Andrés, Obras Completas de don Andrés Bello, Opúsculos Jurídicos, Volumen IX, Impreso por Pedro G. Ramírez Bello, Santiago, 1881-1883. 
Binder, Alberto; Obando, Jorge, De las "Repúblicas Aéreas" al Estado de Derecho, Editorial AdHoc, Buenos Aires, 2004.

BobBio, Norberto, El futuro de la democracia, traducción José Fernández Santillán, Fondo de Cultura Económica, México, 1986.

Bordalí Salamanca, Andrés, "Independencia y responsabilidad de los jueces", Revista de Derecho (Valdivia), 2003, Vol. 14 (jul), pp. 159-174.

Bravo Lira, Bernardino, Historia de las instituciones políticas de Chile e Hispanoamérica, Editorial Andrés Bello, Santiago, 1986.

Calamandrei, Piero, Proceso y democracia, traducción por Héctor Fix Zamudio, Ediciones Jurídicas Europa - América, Buenos Aires, 1960.

CAlamandrei, Piero, Elogio de los jueces escrito por un abogado, traducción por Santiago Sentís e Isaac J. Medina, Góngora, Madrid, 2009.

Domínguez Águila, Ramón, "La constitucionalización del derecho", en Navarro, E. (ed.), 20 años de la Constitución Chilena: 1981-2001, Ed. Jurídica ConoSur, Santiago, 2001.

FerRAJOLI,Luigi, "El juezen una sociedad democrática”, Conferencia en elPrimer Congreso de la Asociación Costarricense de la Judicatura, Costa Rica, 1997 (traducción de Perfecto Andres I.), documento pdf (15 p.), disponible en línea: http://biblioteca. cejamericas.org/bitstream/handle/2015/1887/eljuezenunasociedemocratica. pdf? sequence=1\&isAllowed=y (fecha de visita: 10 de agosto de 2019).

Ferrajoli, Luigi, "Pasado y futuro del Estado de derecho", Revista Internacional de Filosofía Política, 2001, n 17, pp. 31-45.

Ferrajoli, Luigi, Derechos y Garantías. La ley del más débil, Trotta, Madrid, 2002.

Furet, François; Halévi, Ran, La Monarchie Republicaine, Fallard, París, 1996.

GARAPÓN, Antoine, Juez y democracia, Editorial Flor del Viento, Barcelona, 1997.

García, José; Verdugo, Sergio, ¿Hacia el Gobierno de los Jueces? Activismo Judicial en Chile, Eds. Libertad y Desarrollo, Santiago, 2014.

García del Corral, Ildefonso (dir.), Cuerpo del Derecho Civil Romano, Ed. Jaime Molinas, Barcelona, 1892, Tomo I.

García Pascual, Cristina, Legitimidad democrática y Poder Judicial, Edicions Alfons el Magnanim, Valencia, 1996.

GÉNY, François, Método de interpretación y fuentes en derecho privado positivo, Ediciones Olejnik, Argentina, 2018.

Grossi, Paolo, Mitología jurídica de la modernidad, traducción Manuel Martínez Neira, Trotta, Madrid, 2003.

Guastini, Riccardo, Estudios de teoría constitucional, Fontamara, México, 2001 .

HamiLton, Alexander, "El federalista: Ensayo LXXVIII", en Hamilton, A.; 
Madison, J.; Jay, J., El federalista, Fondo de Cultura Económica, México, 1982, pp. 330-336.

Hanisch, Hugo, "Contribución al estudio del principio y de la práctica de fundamentación de las sentencias en Chile durante el siglo XIX", Revista de Estudios histórico-jurídicos, 1982, VII, pp. 131-173.

Hilbink, Lisa, Jueces y politica en democracia y dictadura. Lecciones desde Chile, traducción por Felipe Millán Zapata, Flacso, México, 2014.

ÍñIguEz, Diego, El fracaso del autogobierno judicial, Thomson Civitas, fundación Alfonso Martín Escudero, Madrid, 2008.

LóPEz GuERrA, Luis, El poder judicial en el Estado constitucional, Palestra, Lima, 2001.

Lousada, José; Ron Latas, Pedro, La independencia Judicial, Dykinson, Madrid, 2015.

Montero Aroca, Juan, Sobre la imparcialidad del juez y la incompatibilidad de funciones procesales, Tirant lo Blanch, Valencia, 1999.

Montesquieu, El espíritu de las leyes, Librería General de Victoriano Suárez, Madrid, 1906, T. I.

Müller, Ingo, Los Juristas del Horror. La "justicia” de Hitler: El pasado que Alemania no puede dejar atrás, traducción por Carlos Armando Figueredo, CTUM, Caracas, 2007, 2ª reimpresión.

Nieto, Alejandro, El desgobierno judicial, Trotta, Madrid, 2005.

Opinión: "El resto es ingenuidad", publicada en periódico La Tercera P.M., edición digital, 10 de marzo de 2018, documento disponible en línea: https:/www. latercera.com/la-tercera-pm/noticia/el-resto-es-ingenuidad/128806/ (fecha de consulta: 23 de marzo de 2019).

PICAdo, Carlos, "El Derecho a ser juzgado por un juez imparcial", IUDEX, 2014, No II (agosto), pp. 31-62.

PlazA, Manuel, Las garantías de la independencia judicial, Gráfica Clemares, Madrid, 1954.

Troper, Michel, "La V République et la séparation des pouvoirs", Droits Revue Française de Théorie, de Philosophie et de culture juridique (Paris), 2006, I, n ${ }^{\circ} 43$, pp. 33-44.

Zagrebelsky, Gustavo, El derecho dúctil. Ley, derechos, justicia, traducción Marina Gascón, Trotta, Madrid, 2011.

b) Normativa

Constitución Política de la República de Chile

Código Orgánico de Tribunales

Código Procesal Penal

Código de Procedimiento Civil 
Código del Trabajo

Ley 19.968 que crea los Tribunales de Familia

c) Jurisprudencia

Tribunal Superior de Justicia de Madrid (España), 7 de julio de 2017, n $416 / 2017$.

Tribunal Superior de Justicia de Madrid (España), 21 de julio de 2017, $\mathrm{n}^{\circ} 465 / 2017$. 